\title{
On the Vesicular Vessels of the Onion.
}

\author{
BY \\ A. B. R E N D L E, B.A., \\ Scholar of St. John's College, Cambridge, Assistant in Botany, \\ British Museum.

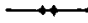 \\ With Plate XII.
}

ANSTEIN ${ }^{1}$ discovered these structures in various
species of Onion, and grouped them with the rows of raphide-containing sacs found in many Monocotyledons as 'vesicular-vessels' (Schlauchgefässe). Excepting a brief description in De Bary's Anatomy ${ }^{2}$, mainly a résumé of Hanstein's results, there does not appear to be any other account of them, nor have they yet been anywhere adequately figured. The account that follows shows that these 'vesicular-vessels' are not at all well named. They are not cell-fusions, and continuity between the contents of adjacent members can very rarely be seen; hence the term 'vessel' is inapplicable, they are simple cells. I-should like therefore, following a suggestion made by Dr. Vines, to replace the distinguishing name they have hitherto borne by the term 'laticiferous cells.'

Development and Distribution. Hanstein gives no account of their development beyond suggesting in a general way the difficulty of finding the primitive structures in the very young parts, and assuming by analogy with Tradescantia, in which he describes the development of the raphide-containing vessels,

1 Monatsschr. Berlin. Acad. 1859, p. 705 .

2 De Bary, Comp. Anat. of Phanerog. and Ferns, Eng. edit. p. 147. [Annals of Botany, Vo1. III. No. X, May 1889.] 
that a similar development is common to all the genera where 'vesicular-vessels' are found; i. e. that they are formed from rows of cells by absorption of the transverse walls. Investigation shows, however, that in the onion each segment originates from a single cell which is at first not very much longer than the cells of the neighbouring parenchyma, but distinguished from these by its very large oval nucleus, and by its contents staining more deeply with iodine and the aniline dyes, especially Hofmann's blue. This is well seen in tangential and radial sections of the base of an internal succulent leaf which has not yet begun to grow out (Fig. I).

Rows of somewhat elongated cells run longitudinally, parallel to the epidermis and separated from it by usually two layers of parenchyma. The transverse septa are not yet pitted, and sections treated (after Gardiner) for several seconds with strong sulphuric acid containing methyl-violet show no signs of communication between the members of the series, -through the swollen cell-walls. With the outgrowth of the leaf from the bud the cells become proportionately elongated, and the transverse walls soon assume the usual pitted appearance figured by Hanstein. In the succulent base of an elongated leaf the cells remain comparatively short, and at the extreme base are very short, and here the longitudinal series are irregularly connected, as Hanstein states, by cross unions (Fig. 6). In this succulent leaf-base they are almost invariably separated from the epidermis by two layers of parenchyma, rarely by one only; in the green tubular part of the leaf, however, they often lie a little deeper, being just below the chlorophyll-containing palisade tissue, i. e. between the more special assimilating tissue and the elongated cells containing comparatively few chlorophyll-corpuscles between which the vascular bundles run (Fig. 4). Here too the laticiferous cells are much elongated.

. In the bulb-scale, as Hanstein states, two series are frequently found running alongside each other, and the wall separating them longitudinally is then also pitted; when parenchymatous cells abut on them the dividing wall is simple. 
I have given a figure of the former case as none has hitherto been published (Fig. 2).

The rows of cells end bluntly at the extreme base and apex of the leaf; no sign of any connection whatever with either the vascular bundles or the assimilating tissue can be seen; nor do they follow the course of the bundles at all. We find them very early in the life of the plant. In the first leaf of the seedling, which pushes up through the soil as a pointed arch and subsequently carries the seed up in the air, a longitudinal section shows the laticiferous cells in their usual position throughout the whole length of the leaf; the transyerse septa are here thin and unpitted.

Contents. As Hanstein pointed out, the cells are filled with a more or less granular turbid fluid which appears on the cut surface of an onion as a pale milk; in the green leaves the contents are clearer and more watery than in the succulent leaf-scales. I cannot find that any food-substances are present ; there is no starch or sugar, though glucose is present in large quantities in the surrounding cells. Fats cannot be detected; and the ordinary microchemical proteid-tests, e.g: Millon's, and the xantho-proteic, give purely negative results, and the usual proteid-solvents, such as salt-solution (to per cent. and saturated), I per cent. or 5 per cent. potash, cause no apparent diminution of the contents, if sections be watched under the microscope while running in the reagent. The action of 5 per cent. potash for nearly two hours is without apparent effect. Carbohydrate, fatty and proteid-food-stuffs are therefore presumably absent, at any rate in quantities appreciable by the existing methods of microchemistry. The contents appear to consist merely of à resinous excretion soluble in alcohol. Hanstein says that calcium-oxalate never. occurs, but it can be found in the laticiferous cells as well as in the surrounding parenchyma at the base of the succulent leaf, in the form of long crystals.

Structural Changes. On first examining these cells ${ }^{1}$, there

1 Vines and Rendle, Proc. of Camb. Phil. Soc., I 886: 
were seen on many of the transverse walls little nodules staining bright red with corallin-soda and bright blue with Hofmann's blue; in fact reacting exactly like the callus of sieve-tubes and evidently consisting of the same substance. As this was first noticed in a resting onion, it seemed probable that, like sieve-tubes, the cells were only actively functional during vigorous growth and closed in seasons of rest. Resting onions were accordingly germinated, but the callus did not disappear, a result to be expected, since the succulent leaves being merely food-reservoirs do not return to active life, but are gradually used up as the shoot grows out. I have since carefully examined a great many specimens in different stages from young seedlings upwards, with the following results.

In the first green leaf of the seedling the elongated cells contain no callus, but their transverse septa are thin and unpitted. In the green leaf of a seedling only $6 \frac{1}{2}$ inches long little nodules of callus are present on the transverse septa, chiefly at the corners where they join the side walls; this was found in about three-fifths of the individuals examined of vigorously growing seedlings in warm sunny weather at the beginning of June.

Examination of the parts of an ordinary small spring-onion, e.g. one with two green leaves and a bulb of about half-aninch maximum diameter, shows the following distribution of callus-formation :-

I. Succulent base of external green leaf. Callus frequent and extensive on all the transverse septa and occasionally on the side walls; the cells well filled with the latex (Fig. 3).

2. Succulent base of next internal green leaf. Nodules of callus found on the majority of the transverse walls, but less in quantity than in $\mathbf{I}$.

3. Unelongated leaf enclosed by $\mathrm{I}$ and 2 . Just green at the tip. No trace of callus in the cells, which are still very small. In a similar leaf from another similar onion there was a very partial callus on about half the number of transverse septa examined (Fig. 2), but the leaf enclosed within this and about half an inch long showed no callus at all, the 
cells being of course in an extremely young state and very short.

4. Portion of leaf between the succulent base and the green tubular part. The very elongated cells show nodules of callus on the transverse septa.

5. Piece of green tubular leaf just above the colorless sheathing part. Small callus-formations on almost all the transverse septa examined and occasionally on the side walls (Fig. 4). The next younger tubular leaf, about a quarterinch below the apex, shows similar small callus-plugs on several of the transverse septa examined, though not on all.

In the succulent leaf-scales of a resting onion there was callus on nearly all the transverse septa examined, and occasionally on the side walls; but in the shoot enclosed in the centre, where the tissue is of course very young, there was none on the thin unpitted transverse septa. If, however, the onion is set to germinate, the leaves of the shoot which grows out soon show a formation of callus, which is also found, just as before, in the cells of the succulent sheath-scales.

From these observations it is evident that, except in the youngest stages, and even before the transverse septa become conspicuously pitted, callus-formation occurs upon them; at first usually as small plugs, afterwards often of a more irregular form and sometimes spreading more or less over the whole plate. The complete covering of both sides, such as obtains in sieve-tubes during winter, is very rarely seen, one instance is noticed in Fig. 3, $b$.

I have repeatedly tested sections from the different parts of leaves of all the ages and in all the conditions mentioned above, to see if the pits in the walls were ever perforated, using for the purpose (after Gardiner) concentrated sulphuric acid in which methyl-violet was dissolved; or chlorzinciodine followed by staining with picro-Hoffmann's blue. The only cases in which perforation was observed occurred in the succulent leaf-scales of a spring-onion in which tangential sections from the lower half of the leaves showed the contents to be continuous through the swollen pits of the transverse 
septa, which were apparently free or almost free from callus. Where this continuity was noticeable it was so obvious (Fig. 5) that its apparent absence in the great majority of cases is probably due, not to difficulty of observation, but to the actual fact of its absence. In the external succulent leaf of the shoot in the centre of a spring-onion, where small nodules of callus were found on about half the transverse-septa examined,-that is, where its formation was only just commencing, and where therefore, if anywhere, demonstration of continuity should be possible,-no indication of such could be found (cf. Fig. 6). The same was the case in very young stages where neither callus or pitting was visible. Not infrequently in sections where no continuity of the contents of the vesicular cells was indicated, protoplasmic continuity between the parenchymatous cells was very well shown.

In the green leaves pitting is less conspicuous and perforation could never be made out.

De Bary says the pits are not perforated, and from the present observations this would seem to be the case in the great majority of instances. At any rate, we cannot trace any direct relation between their perforation or closure and the activity of the vital processes in the plant, such as obtains with sieve-tubes. All that can be said is, that in the succulent basal leaves of young onions, in the lower half only of which perforations were observed, continuity between the contents of adjacent members of the series sometimes occurs; and it is here that our cells are most numerous and closest together, and that the longitudinal series are connected by cross-unions. The degree of protoplasmic continuity is evidently altogether insufficient to justify the application of the term 'vessel' to these structures. It is in fact no more extensive than that obtaining between parenchymatous cells.

$\mathrm{It}_{\boldsymbol{q}}$ is interesting from this point of view that callus-formation occurs where there is no evident pitting. Thus, in a young leaf of the shoot of an old onion which had germinated, out of six transverse walls examined, five showed no trace of callus, but the sixth: which was not pitted and scarcely thicker 
than the thin side wall, stained like callus, though somewhat faintly, for about a third of its length in its central portion, while just at the end of the stained part a very small more brightly staining blunt peg projected into the cell on one side (Fig. 7).

This and similar cases are of interest as regards the question whether callus is formed from the cell wall or secreted directly by the protoplasm. With regard to the participation of the wall in the formation of callus the following differences were noticed:-

- I. The wall itself is not changed, but the callus is superposed sometimes only on one (Fig. $3, a$; and 2, a), sometimes correspondingly on both sides (Fig. $3, c, d$; and 2, $\beta$ ).

2. The wall gives the callus-reaction, but more faintly than the superposed formation, and it can by virtue of this be traced through the callus masses where these correspond in position on both sides of the plate (Fig. $3, a, b, d$ ).

3. The wall cannot be distinguished at all ; the staining is of a uniform tint throughout (Fig. 3, $b, c$ ).

The first case is more frequent where there is only a small callus-formation; either the second or the third usually obtains where the callus is more extensive, but sometimes where only very partial. With very extensive callus-formations, the side walls sometimes stain for a little distance beyond the transverse septum, the colour of the stain becoming fainter and fainter and gradually passing into the ordinary nonstaining cellulose (Fig. 3, b, lower plate). These facts point to a change induced in the cellulose of the wall by which it becomes more (as in 3) or less (as in 2) converted into callus, as indicated by more or less deep staining, while pure callus is deposited on this by the protoplasm in the same way as thickening on a wall.

Function. As stated above, these laticiferous cells contain none of the ordinary food-stuffs in any perceptible quantity, nor have they any connection with the assimilating parenchyma on the one hand, or with the vascular bundles on the other. There seems to be no direct relation between presence 
of callus on the walls and the general vigour of the life of the plant or its members. The resemblance to sieve-tubes is simply structural; and it may be noticed that these members of the vascular bundles of the onion are by no means few or feebly developed, so as to necessitate any additional means of transport for nutrient substances. These vesicular cells are evidently merely rows of excretory sacs which begin to be sealed up by callus very early, the smaller amount of callus in the green leaves corresponding with the less evident pitting found there. This view of their function is confirmed by the following observation. In the germination of a resting onion which had produced a vigorous shoot a foot high, and in which the formerly succulent leaves were being used up from the outside inwards, the vesicular cells in the now quite membranous scales were still crowded with the resinous latex, and became marked out as pink lines in the leaf on placing pieces in dilute alcanna-tincture. The transverse septa were still callosed, while the nuclei had almost completely broken down. Thus, at a time when the tissue had been so drawn upon to supply the growing shoot, as to reduce the leaf to the consistency of thin paper and to render it quite transparent, these laticiferous cells were still full of what must I think be therefore regarded as a purely excretory substance, one, that is, of no further use to the plant as a food-stuff. No other excretory structures are found in the tissues of the stem and leaves of the onion. Doubtless the resinous latex is of some use in the life of the plant, perhaps making it unpalatable to certain animals, or keeping them off by the peculiar smell. This smell is due to some substance which gives rise to allylsulphide when an onion is analysed, and which is probably contained in the latex, since a silver coin is slightly blackened thereby; but, though I have tried a great number of microchemical tests, I have never succeeded in demonstrating that this compound is localised. It is probably only present in small quantities, the detection of which is made practically impossible by the presence of so much resinous substance, for resins greatly interfere with the tests. 


\title{
EXPLANATION OF FIGURES IN PLATE XII.
}

\author{
Illustrating Mr. Rendle's paper on the Vesicular Vessels of the Onion.
}

N.B.-In the case of sections mounted in corallin-soda the depth of stain of the callus is represented by the degree of shading. The letters D, F, refer to Zeiss' objectives: 2, to his eye-piece.

Fig. I. Longitudinal section of the base of a young internal leaf of a springonion. $a$, row of young vessels; $e$, epidermis. The section had been treated with haematoxylin, and the contents of the vessels had stained deeply. D, 2.

Fig. 2. Tangential section of an internal succulent leaf of a spring-onion. The leaf had not begun to elongate. Mounted in corallin-soda to show the callus, which is very scanty. $D, 2$.

Fig 3. From tangential sections of the base of the outside leaf of a spring-onion with two green leaves and a bulb of half-an-inch maximum diameter. Monnted in corallin-soda. Shows the callus-formation on the transverse septa and occasionally the side walls of the vessels. $a, b, \mathrm{D}, 2 ; c, d, \mathrm{~F}, 2$.

- Fig. 4. Longitudinal section of a piece of a green tubular leaf just above the colorless sheathing part. Mounted in corallin-soda. $a$, vesicular vessel; $e$, epidermis with very thick and coticularised outer walls; $\not$, chlorophyll-containing parenchyma; $t$, shows a transverse septum with a callus-stopper. Mounted in corallin-soda. D, 2.

Fig. 5. From tangential sections of the base of an outside succulent leaf of a spring-onion treated with chlorzinc-iodine for twenty-four hours, and then, after thorongh washing, with picro-Hofmann's blue for twenty hours. Examined in water after again thoroughly washing. The contents of the vessels can be seen passing through the pits in the swollen transverse septa. F, 2 .

Fig. 6. Tangential section of an unelongated leaf of the shoot in the centre of a spring-onion treated for a few seconds with sulpharic acid and methyl-violet, and then thoroughly washed. No sign of connection between the deeply-stained contents of the young vessels. Shows cross-unions between two rows of vessels. D, 2.

Fig. 7. Transverse septum from a young leaf of the shoot enclosed in a germinating onion. Mounted in corallin-soda. Shows partial staining of the wall with the dye, and also a little brightly staining knob to the right of this. F, 2 . 
Fig. I. a e

Fig. 2
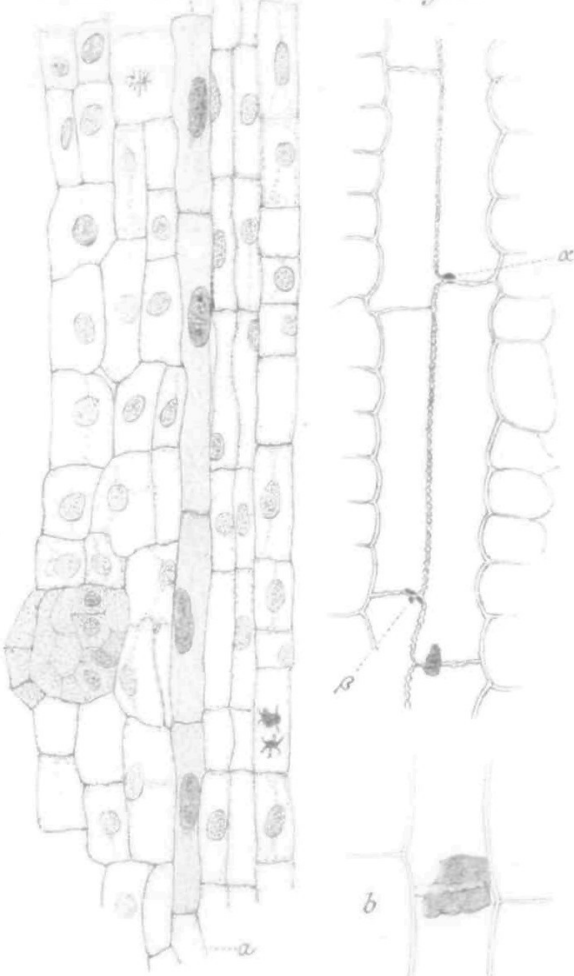

Fig. 5.
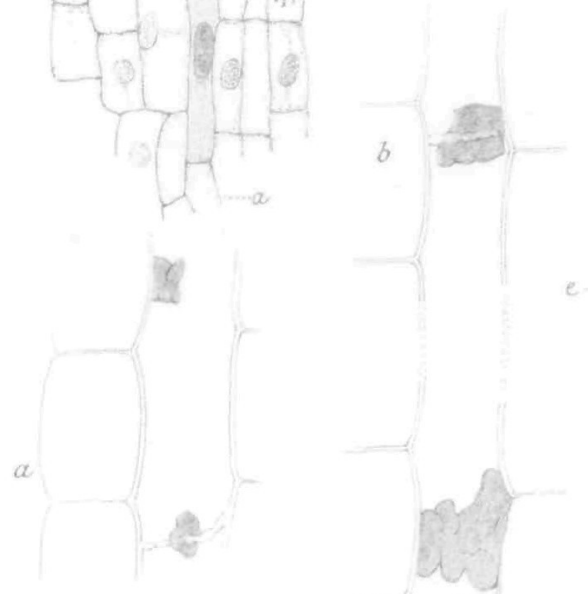

8 Fig. 3 .

c

48
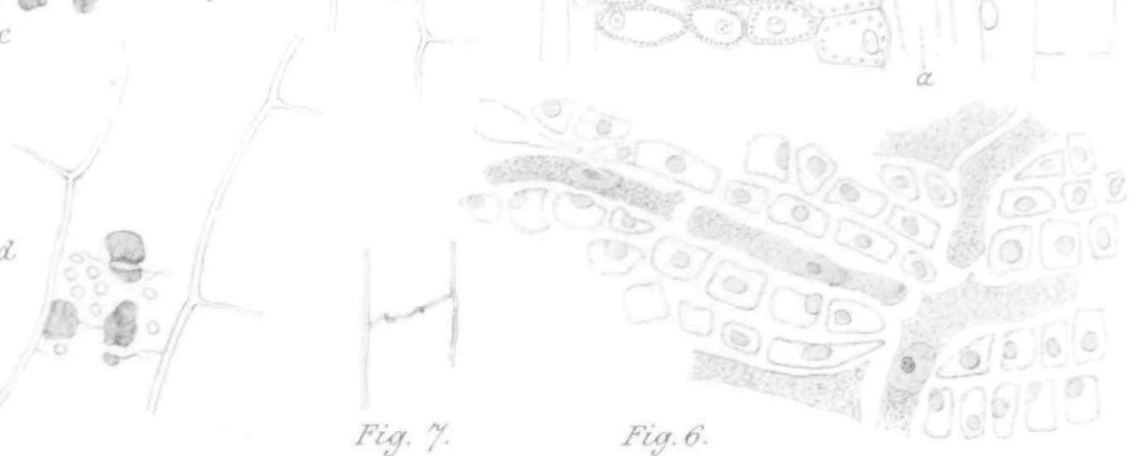